\title{
The Valuation Implications of Employee Stock Option Accounting for Profitable Computer Software Firms
}

\author{
Timothy B. Bell \\ KPMG LLP \\ Wayne R. Landsman \\ The University of North Carolina at Chapel Hill \\ Bruce L. Miller \\ University of California, Los Angeles \\ Shu Yeh \\ National Taiwan University
}

\begin{abstract}
We use the Ohlson $(1995,1999)$ and Feltham and Ohlson (1999) valuation models to investigate the market's perception of the economic effect of employee stock options (ESOs) on firm value for a sample of 85 profitable computer software companies. Our results suggest that the market appears to value these firms' ESO expense not as an expense but as an intangible asset (even after controlling for the endogeneity bias arising from the mechanical relation between ESOs and the underlying stock prices). However, we also find a conflict between: (1) the positive manner in which investors appear to value ESO expense, and (2) the negative relation between current ESO expense and future abnormal earnings. This conflict not only could be an artifact of the restrictiveness of the abnormal earnings forecasting equation we estimate, but it also calls into question whether investors assess correctly the effect of ESOs on profitable software firm value.
\end{abstract}

We appreciate comments from workshop participants at the 2001 American Accounting Association Annual Meeting, particularly the discussant, Wayne Guay, the 2000 Southeast Accounting Summer Research Colloquium, Harvard Business School, the University of Florida, National Chengchi University, National Cheng Kung University, and National Taiwan University. We also thank the anonymous reviewer who provided substantial insights, Karen Bell for editorial assistance, and funding from the Center for Finance and Accounting Research at The University of North Carolina at Chapel Hill. 
Keywords: ESO asset; ESO expense; vesting period; abnormal earnings; pre-
paid compensation asset.

Data Availability: Data are available from the authors.

\section{INTRODUCTION}

$\mathrm{E}$ mployee stock options (ESOs) comprise a sizable portion of executive compensation (Hall 2000, 121; Business Week 2002), but financial statement preparers, financial statement users, regulators, and standards setters disagree on how ESOs should be reflected in the financial statements. In June 1993, the Financial Accounting Standards Board (FASB) released Exposure Draft: Accounting for Stock-Based Compensation (FASB 1993) (hereafter Exposure Draft). The Exposure Draft would have required employers to recognize as an intangible asset the fair value of stock options at the grant date, to amortize this asset, and to record the asset's amortization as employee compensation expense.

Two years later, in October 1995, and after more than a decade of deliberations, the FASB issued Statement of Financial Accounting Standards No. 123, Accounting for StockBased Compensation (FASB 1995) (hereafter SFAS No. 123). SFAS No. 123 requires firms to disclose (in footnotes to the financial statements) the pro forma effects on earnings of employee compensation expense attributable to amortizing the fair value of employee stock options at the grant date. However, SFAS No. 123 does not generally require firms to recognize this ESO-related compensation expense in the income statement, although it encourages firms to do so. Instead, SFAS No. 123 permits firms to use Accounting Principles Board Opinion No. 25, Accounting for Stock Issued to Employees (AICPA 1972) (hereafter APB No. 25), which allows the firm not to recognize employee stock compensation expense if the grant meets two requirements at the grant date: the exercise price and the number of options are fixed, and the exercise price equals or exceeds the stock price. Most companies have been careful to meet these two requirements, presumably to avoid recognizing stock option-related expense in the income statement.

In this study, we use the Ohlson $(1995,1999)$ and Feltham and Ohlson (1999) valuation models to compare the extent to which the APB No. 25, SFAS No. 123, and the Exposure Draft approaches to accounting for employee stock options reflect the market's assessment of the effects of employee stock options on firm value for a sample of 85 profitable computer software firms. In particular, we focus on whether investors view ESO expense disclosures required by SFAS No. 123 differently from other components of income. ${ }^{1}$ Investors may value ESO expense differently because stock options align the interests of employees and shareholders. Because employee stock options motivate employees to boost productivity, profits, and especially stock price, Stewart (1997, Chapter 6) suggests that employee stock options give rise to a valuable intangible asset. Furthermore, this incentive-aligning motivation extends beyond the vesting period (the period over which SFAS No. 123 requires firms to expense options) to the time that employees exercise their options. This raises the possibility that an intangible asset exists even beyond the vesting period. Thus, unlike most expenses, investors may view ESO expense as providing information about an unbooked intangible asset as well as an expense.

The motivational advantages of employee stock options are likely to be more important in knowledge-intensive industries with significant intellectual capital, such as the computer software industry. Engel (1997) reported that software firms had the highest ratio of options

${ }^{1}$ Unless we state otherwise, "stock option expense" refers to stock option expense based on SFAS No. 123 disclosures, i.e., based on amortization of the fair value of employee stock options. 
granted to shares outstanding of any industry. Thus, we focus our analysis on the software industry because it provides us with a powerful setting to explore the extent to which the three methods of accounting for employee stock options reflect the market's assessment of the effects of employee stock options on firm value. We restrict our sample to software firms with positive net income to ensure the valuation model is well specified.

Using a valuation model following from SFAS No. 123-which includes the disclosed ESO expense but not the estimate of the ESO asset-we find that the market appears to value ESO expense not as an expense but as an asset. That is, the market appears to value the ESO expense as if it serves as a proxy for an intangible asset associated with issuance of employee stock options that we omit from the valuation model.

When we use a valuation model following from the Exposure Draft-which includes an estimate of the ESO asset as well as the ESO expense-we find that the ESO asset (measured as amortized fair value of employee stock options) is highly value-relevant, even more so than other assets of the firm. This result is consistent with employee stock options creating a valuable intangible asset, i.e., contributed intellectual capital. Surprisingly, our results suggest that investors continue to value ESO expense as an asset even when we include the ESO asset in the valuation model. This suggests that the amortized ESO asset may not capture fully the future net economic benefit that investors expect the firm to reap as a result of issuing the employee stock options. When we repeat this analysis including the unamortized (gross) ESO asset in the valuation model, ESO expense is no longer valuerelevant. These results are consistent with investors believing that the intangible asset has a useful life longer than the option-vesting period.

In contrast with the positively valued ESO expense, we find that the market negatively values selling, general, and administrative expense (SG\&A), which includes the compensation expense paid to employees engaged in administrative and marketing activities. Thus, our results suggest that for profitable software firms, investors value ESO expense differently from other components of income, and differently from other forms of compensation as reflected in SG\&A.

Our results suggest that the approach proposed in the Exposure Draft on accounting for stock-based compensation better reflects the market's perception of the effect of employee stock options on profitable software firms' value. In particular, our results are consistent with investors in profitable computer software companies perceiving that employee stock option grants create a valuable asset or investment.

Our study extends the literature examining how investors assess the relation between ESO information and equity values. Aboody (1996) finds a significant negative relation between his estimate of the fair value of outstanding employee stock options and equity market value after controlling for the endogeneity bias induced by the mechanical relation between option values and share prices. Aboody (1996) must estimate ESO fair values because his sample period predates SFAS No. 123. Using data obtained from SFAS No. 123 disclosures, Aboody et al. (2001) and Chamberlain and Hseih (1999) find a negative association between ESO expense and equity value after controlling for the endogeneity bias in a manner similar to Aboody (1996). In contrast to these studies that document a negative effect of employee stock options on firm value, we find a positive association between ESO expense and equity value, even after controlling for endogeneity bias.

Differences between our findings and those of Aboody et al. (2001) and Chamberlain and Hseih (1999) are most likely attributable to sample differences. In particular, sample firms in the other two studies represent a broader set of industries and are not necessarily profitable. It is possible that employee stock options create a valuable intangible asset for profitable firms in knowledge intensive industries, but not for firms in other industries. The 
evidence in Keating et al. (2002), that their measure of the fair value of employee stock options that Internet firms granted in 1999 is significantly positively associated with equity value, supports our conjecture.

None of these other studies investigates the value-relevance of ESO assets measured in accordance with the Exposure Draft, yet we find that this approach to accounting for employee stock options better reflects the market's perception of the effect of employee stock options on profitable software firms' value. However, we cannot use our conclusions as a basis for a general policy recommendation. First, the generalizability of our inferences beyond knowledge-intensive industries is open to question. Second, we find a conflict between the positive manner in which investors appear to value ESO expense, and the negative relation between current ESO expense and future abnormal earnings. This conflict could be an artifact of the restrictiveness of the simple first-order autoregressive abnormal earnings model we estimate. However, it also calls into question whether investors correctly assess the effect of employee stock options on profitable software firms' value.

We organize the remainder of the paper as follows: Section II develops the research design and our predictions; Section III describes the sample and data; Section IV presents the primary findings; Section V presents findings from additional analyses; and Section VI summarizes and concludes the study.

\section{RESEARCH DESIGN \\ Description of Alternative Accounting Methods}

Prior to SFAS No. 123, APB No. 25 required firms to use the intrinsic value method to account for employee stock options. The intrinsic value of an option is the difference between its exercise price and the current price of the underlying stock. Intrinsic value excludes the value of the right to purchase the underlying stock at a fixed price for a specified future period. APB No. 25 requires employers to record stock option compensation cost as the difference between the market price of the stock and the amount an employee must pay to acquire the stock on the measurement date (i.e., when the employer knows the number of shares to which employees are entitled and their exercise price). For most ESOs, the measurement date and grant date are the same, although the measurement date may be later if there is uncertainty at grant date regarding the exercise price or the number of shares the employee may acquire.

APB No. 25 does not require employers to recognize or disclose compensation expense for fixed-award employee stock options (i.e., at the grant date, the employer knows the number of shares to which an individual employee is entitled to purchase and their exercise price) if the exercise price equals or exceeds the stock price at grant date. Paragraph 56 of SFAS No. 123 criticizes APB No. 25's use of the intrinsic value method because it allows such nonrecognition while treating performance options, which may be less valuable than fixed options at the grant date, as compensation costs that might have to be recognized. (The number and exercise price of performance options depend on the manager's achievement of a contractual measure of performance.) The business press criticized APB No. 25 as well (e.g., Morgenson 1998; The Economist 1999).

Because of these criticisms, coupled with the increasing use of stock options in lieu of salary and cash bonuses during the 1980s, the FASB began work on an alternative to APB No. 25. In 1993, the FASB issued the Exposure Draft that would have required employers: (1) to recognize the asset Prepaid compensation for the fair value of granted stock options at their grant date, and (2) to recognize the related compensation expense from amortizing 
that asset over the options' vesting period. ${ }^{2}$ The offsetting entry credits the equity account Options outstanding and is extinguished only as options are forfeited, expired, or exercised.

In paragraph 63 of the Exposure Draft, the FASB defends creating the Prepaid compensation asset by stating, "employee stock options represent probable future benefits because employees have agreed to render future services to earn their options. Stock options also reduce future cash outflows otherwise necessary to compensate employees." The Exposure Draft engendered much controversy, most notably from preparers who were concerned by the prospect of deducting stock option-related employee compensation expense in the income statement.

With the issuance of SFAS No. 123 two years later, the FASB yielded to political pressure while acceding to its critics. SFAS No. 123 suggests that employers estimate the fair value of an employee stock option at grant date using standard option-pricing models (e.g., the Black-Scholes option valuation model). SFAS No. 123 then allows firms either to disclose pro forma or to recognize the effects on earnings of employee compensation expense, computed by amortizing the fair value of employee stock options over the vesting period. Virtually all firms choose the pro forma disclosures rather than recognizing compensation expense on the income statement. Whereas the Exposure Draft would have required employers to recognize and amortize Prepaid compensation and Options outstanding at grant date, SFAS No. 123 requires firms only to make a memo journal entry for the fair value of the employee stock options at grant date, and permits, but does not require, amortizing the fair value of the options over the option-vesting period. ${ }^{3}$ Table 1 summarizes the accounting treatments under the three accounting methods.

\section{Benchmark Valuation Equations Based on APB No. 25}

This paper uses the Ohlson $(1995,1999)$ and Feltham and Ohlson (1999) valuation models to compare the extent to which the APB No. 25, SFAS No. 123, and Exposure Draft methods of accounting for employee stock options reflect the market's assessment of firm value. In the valuation equation, the dependent variable is market value of common shares outstanding, and the two independent variables are abnormal earnings and book value of common equity. Following the theoretical work of Ohlson (1999) and Feltham and Ohlson (1999), and the empirical application of Ohlson (1999) by Barth et al. (1999), we also estimate a first-order abnormal earnings forecasting equation for which the dependent variable is abnormal earnings and the independent variables are previous year's abnormal earnings and book value of common equity. Assuming that error terms of the first-order abnormal earnings forecasting equation are unpredictable with a mean of zero, Ohlson $(1999,151)$ shows that the coefficients of the independent variables in the forecasting equation determine the independent variables' relative importance in the valuation equation. Ohlson's (1999) result-linking the abnormal earnings equation with the valuation equation-is intuitive. It implies that abnormal earnings are more important in valuation if current abnormal earnings are more predictive of next year's abnormal earnings.

Because none of our sample firms recognize ESO expense per SFAS No. 123, reported earnings and book values of common equity reflect the APB No. 25 method of accounting

\footnotetext{
2 An employee's option grant vests at the date that the employee's right to receive or retain stock is no longer contingent on remaining in the employer's service.

. SFAS No. 123 does not allow employers to recognize the asset, Prepaid compensation. The Board agreed with respondents to the Exposure Draft that firms should not recognize Prepaid compensation because employees are not obligated to render the services required to earn the vesting rights associated with the options.
} 
TABLE 1

Financial Accounting Treatments of Employee Stock Options ${ }^{\mathrm{a}}$

Accounting Method
Continue APB No. 25/
SFAS No. 123
disclosure
Adoption of SFAS No.
123 compensation
expense recognition

Exposure Draft on stockbased compensation

\author{
Grant Date \\ No entry \\ No entry
}

Dr. Compensation cost

Cr. Paid-in capital-

\author{
Dr. Prepaid \\ compensation \\ Cr. Options \\ outstanding
} Employee stock options

$\frac{1}{\text { End of Year }}$
No entry
Dr. Compensation cost
Cr. Paid-in capital-
Employee stock
options

Dr. Compensation cost

Cr. Prepaid compensation

\author{
Exercise Date \\ Dr. Cash \\ Cr. Common stock
}

Dr. Cash

Dr. Paid-in capitalEmployee stock options

Cr. Common stock

Dr. Cash

Dr. Options

outstanding

Cr. Common stock

\footnotetext{
${ }^{a}$ Assumes that the stock option is a nonqualified stock option and that the exercise price is set equal to the fair market value of the underlying stock on the grant date. For simplicity, we have omitted the tax-related journal entries.
}

for employee stock options. The benchmark APB No. 25 abnormal earnings and valuation equations are as follows:

$$
\begin{aligned}
\operatorname{AEARN}_{\mathrm{it}} & =\omega_{0}+\omega_{1} \mathrm{AEARN}_{\mathrm{i}, \mathrm{t}-1}+\omega_{3} \mathrm{BVE}_{\mathrm{i}, \mathrm{t}-1}+\varepsilon_{\mathrm{it}}^{\mathrm{A}} \\
\mathrm{MVE}_{\mathrm{it}} & =\alpha_{0}+\alpha_{1} \mathrm{AEARN}_{\mathrm{it}}+\alpha_{3} \mathrm{BVE}_{\mathrm{it}}+\varepsilon_{\mathrm{it}}^{\mathrm{M}} .
\end{aligned}
$$

AEARN $_{t}$ is abnormal earnings and equals $\mathrm{NI}_{t}-\mathrm{rBVE}_{\mathrm{t}-1} ; \mathrm{NI}_{\mathrm{t}}$ equals net income before extraordinary items and discontinued operations for fiscal year $t ; B V E_{t}$ is the book value of common equity at the end of fiscal year $t ; \mathrm{MVE}_{\mathrm{t}}$ is the market value of common shares outstanding at the end of fiscal year $t ; \varepsilon^{\mathrm{A}}$ and $\varepsilon^{\mathrm{M}}$ are error terms; and the $\mathrm{i}$ and $\mathrm{t}$ subscripts denote firms and years, respectively. Following Dechow et al. (1999) and Barth et al. (1999), we set the expected rate of return on book value of common equity, $r$, at 12 percent, the long-term return on equities. The error terms, $\varepsilon^{\mathrm{A}}$ and $\varepsilon^{\mathrm{M}}$, reflect other information as well as random error. For ease of exposition, we use the same notation for coefficients and error terms across alternative pairs of abnormal earnings and valuation equations.

Although defining AEARN based on net income before extraordinary items and discontinued operations violates the clean surplus assumption in Ohlson (1995), it eliminates potentially confounding effects of large one-time items and is consistent with prior empirical research (e.g., Barth et al. 1999, 2000; Dechow et al. 1999; Hand and Landsman 2000). ${ }^{4}$

${ }^{4}$ Ohlson (2000) points out that even bottom line net income will not satisfy the clean surplus equation under the pooling-of-interest method of accounting for business combinations and the APB No. 25 method of accounting for employee stock options. In each case, the problem arises from recording equity transactions using nonmarket prices. Future research undoubtedly will address the importance of Ohlson's (2000) observation for empirical work based on equations similar to Equation (1b). 
Ohlson $(1999,160)$ concludes that this approach is justified in empirical work because onetime items have no forecasting ability.

As Barth et al. $(1999,208)$ observe, including $\mathrm{BVE}_{\mathrm{t}-1}$ in the abnormal earnings equation partially relaxes the assumption that the cost of capital associated with calculating abnormal earnings is a predetermined rate, because current and lagged BVE are highly correlated. In Equation (1a), $\omega_{1}$ reflects the persistence of abnormal earnings. Prior research (e.g., Barth et al. 1999, 2000; Dechow et al. 1999; Hand and Landsman 2000) leads us to expect that $\omega_{1}$, the autocorrelation of abnormal earnings, is positive. Based on Ohlson (1995), we expect $\alpha_{1}$ and $\alpha_{3}$ to be positive.

\section{Valuation Equations Based on SFAS No. 123}

SFAS No. 123 requires crediting the equity account Paid-in capital-Employee stock options when employers debit ESO expense. We do not include Paid-in-Capital-Employee stock options in book value of common equity. Our rationale is that because the dependent variable in the valuation equation is the current market value of common shares outstanding, the related independent variable, book value of common equity, should include only those components of equity that are associated with common shares currently outstanding. Our approach follows Feltham $(1995,16)$, who also excludes obligations to issue equity from book value of common equity. Also note that if we include Paid-in capital-Employee stock options in book value of common equity, then book value of common equity would not drop when firms expense employee stock options. This result differs from other types of employee compensation expense, which lower both net income and book value of common equity.

Under SFAS No. 123 recognition rules, ESO expense reduces net income to defined pro forma net income, with an equal decrease in ending book value of common equity. Therefore, our accounting treatment satisfies the clean surplus equation because the decrease in book value of common equity equals the decrease in net income attributable to ESO expense. 5

Abnormal earnings and valuation equations that result from applying the SFAS No. 123 approach are as follows:

$$
\begin{aligned}
\text { AEARNESO }_{i t} & =\omega_{0}+\omega_{1} \text { AEARNESO }_{i, t-1}+\omega_{3} \text { BVE_ADJ }_{i, 1-1}+\varepsilon_{i t}^{A} \\
\text { MVE }_{\mathrm{it}} & =\alpha_{0}+\alpha_{1} \text { AEARNESO }_{\mathrm{it}}+\alpha_{3} \text { BVE_ADJ }_{\mathrm{it}}+\varepsilon_{\mathrm{it}}^{\mathrm{M}} .
\end{aligned}
$$

MVE is defined previously; AEARNESO, is abnormal earnings and equals $\mathrm{NI}_{1}-\mathrm{rBVE}$ ADJ $_{1-1}$ - ESOEXP, ESOEXP, is ESO expense and equals reported net income less SFAS No. 123 defined pro forma net income; , BVE_ADJ $_{\mathfrak{t}}$ is adjusted book value and equals $\mathrm{BVE}_{1}$ less ESOEXP, accumulated since $1995 ;^{7}$ and $\varepsilon^{\mathrm{A}}$ and $\varepsilon^{\mathrm{M}}$ are error terms. Equations (2a) and (2b) restate earnings and book value of common equity to recognize ESO expense based on SFAS No. 123. If recognizing ESO expense per SFAS No. 123 better reflects

\footnotetext{
s If we include Paid-in capital-Employee stock options in book value of common equity, then our accounting treatment can satisfy the clean surplus equation only by interpreting the credit to Paid-in capital-Employee stock options as an issuance of common stock.

6 ESOEXP is the additional stock option-based compensation expense, net of a provision for income taxes.

7 As Table 1 shows, this adjustment of BVE to obtain BVE_ADJ does not take into account that when employees exercise their options, there is a greater increase in book value of common equity under SFAS No. 123 and the Exposure Draft than under APB No. 25. This does not play a material role for our sample because most options have three-year or longer vesting periods, so those exercised in 1996 through 1998 come primarily from options granted prior to 1995. Options granted prior to 1995 do not cause a problem at the exercise date because accounting rules under APB No. 25 apply rather than SFAS No. 123.
} 
investors' perceptions of the underlying economic reality, then Equation (2b) should have more explanatory power than Equation (1b). We make the same coefficient predictions for Equations (2a) and (2b) as we do for Equations (1a) and (1b), $\omega_{1}, \alpha_{1}$, and $\alpha_{3}>0$.

To assess whether the market values ESOEXP similarly to other components of earnings, we extend Equations (2a) and (2b) by including ESOEXP as an additional independent variable:

$$
\begin{aligned}
\operatorname{AEARNESO}_{\mathrm{it}} & =\omega_{0}+\omega_{1} \mathrm{AEARNESO}_{\mathrm{i}, \mathrm{t}-1}+\omega_{2} \mathrm{ESOEXP}_{\mathrm{i}, \mathrm{t}-1}+\omega_{3} \mathrm{BVE}_{-} \mathrm{ADJ}_{\mathrm{i}, \mathrm{t}-1}+\varepsilon_{\mathrm{it}}^{\mathrm{A}} \\
\mathrm{MVE}_{\mathrm{it}} & =\alpha_{0}+\alpha_{1} \mathrm{AEARNESO}_{\mathrm{it}}+\alpha_{2} \mathrm{ESOEXP}_{\mathrm{it}}+\alpha_{3} \mathrm{BVE}_{-} \mathrm{ADJ}_{\mathrm{it}}+\varepsilon_{\mathrm{it}}^{\mathrm{M}} .
\end{aligned}
$$

If the market values ESOEXP differently from other components of income, then $\alpha_{2}$ will differ from zero. Similarly, if current ESOEXP forecasts future abnormal earnings differently from other components of income, then $\omega_{2}$ will differ from zero. Because ESOEXP is a component of AEARNESO, the total valuation coefficient on ESOEXP equals $-\alpha_{1}$ $+\alpha_{2}{ }^{8}$ Thus, if $-\alpha_{1}+\alpha_{2}=0$, then ESOEXP is irrelevant for valuation. We test the value irrelevance condition $-\alpha_{1}+\alpha_{2}=0$ against the alternative that $-\alpha_{1}+\alpha_{2} \neq 0$. Evidence that ESOEXP is value irrelevant would suggest that investors perceive that APB No. 25's method of accounting for ESOs captures correctly their underlying economic effects on firm value. Analogously, the total autoregressive coefficient on ESOEXP equals $-\omega_{1}+\omega_{2}$. Thus, if $-\omega_{1}+\omega_{2}=0$, then ESOEXP is irrelevant for forecasting abnormal earnings. We test the forecasting irrelevance condition $-\omega_{1}+\omega_{2}=0$ against the alternative that $-\omega_{1}$ $+\omega_{2} \neq 0$.

\section{Valuation Equations Based on the Exposure Draft}

The Exposure Draft on accounting for stock-based compensation would have required employers to debit an asset, Prepaid compensation, at the grant date and to credit Options outstanding. For the same reasons that we do not consider Paid-in capital-Employee stock options as part of book value of common equity in the SFAS No. 123 approach, we also do not include Options outstanding as part of book value of common equity in the Exposure Draft approach. Therefore, BVE_ADJ and the other variables have the same values as in the SFAS No. 123 approach, and Equations (3a) and (3b) also apply to the Exposure Draft approach.

However, just as Equations (3a) and (3b) isolate the ESO expense component of AEARNESO, we now can isolate the Prepaid compensation component of BVE_ADJ (ESOASSET). This is the book value of the Prepaid compensation related to unvested employee stock options outstanding at the fiscal year-end. The abnormal earnings and valuation equations resulting from the Exposure Draft rules are as follows:

$$
\begin{aligned}
\text { AEARNESO }_{\mathrm{it}}= & \omega_{0}+\omega_{1} \text { AEARNESO }_{\mathrm{i}, \mathrm{t}-1}+\omega_{2} \text { ESOEXPP }_{\mathrm{i}, \mathrm{t}-1}+\omega_{3} \text { BVE_ADJ }_{\mathrm{i}, \mathrm{t}-1} \\
& +\omega_{4} \text { ESOASSET }_{\mathrm{i}, \mathrm{t}-1}+\varepsilon_{\mathrm{it}}^{\mathrm{A}} \\
\text { MVE }_{\mathrm{t}}= & \alpha_{0}+\alpha_{1} \text { AEARNESO }_{\mathrm{it}}+\alpha_{2} \text { ESOEXP }_{\mathrm{it}}+\alpha_{3} \text { BVE_ADJ }_{\mathrm{it}} \\
& +\alpha_{4} \text { ESOASSET }_{\mathrm{it}}+\varepsilon_{\mathrm{it}}^{\mathrm{M}} .
\end{aligned}
$$

In comparison to Equations (3a) and (3b), Equations (4a) and (4b) allow the ESO asset

\footnotetext{
8 Viewing the total valuation coefficient as $-\alpha_{1}+\alpha_{2}$ follows the approach adopted by Ohlson $(1999,150)$ and Barth et al. (1999, 209). The same concept applies to the abnormal earnings forecasting equation (Barth et al. 1999, 208).
} 
(ESOASSET) to have a total coefficient that differs from other components of equity book value. If the market does not value ESOASSET as an asset, then $\alpha_{3}+\alpha_{4}=0$. If the market values ESOASSET similarly to other net assets, then we expect $\alpha_{4}=0 .{ }^{9}$ However, if the market values ESOASSET more highly than other net assets, then we expect $\alpha_{4}>0$. Such a finding would support Stewart's (1997, Chapter 6) view that employee stock options give rise to a valuable intangible asset-a form of intellectual capital. We make no predictions for $\omega_{3}$ and $\omega_{4}$.

\section{Estimating ESOASSET}

Because the FASB did not adopt the Exposure Draft, we have to estimate ESOASSET as ESOASSET $_{1}=$ ESOASSET $_{1-1}+$ fair value of ESOs granted in year $t$ - fair value of forfeitures during year $t$ - before-tax ESO expense in year $t$. This updating equation for ESOASSET, is analogous to the updating equation for net property, plant, and equipment. The fair value of employee stock options granted in year $t$ is analogous to new purchases of property, plant, and equipment; forfeitures during the year $t$ are analogous to sales and retirement of net property, plant, and equipment; and ESO expense is analogous to depreciation. The Exposure Draft expected firms to use this updating equation for ESOASSET. ${ }^{10}$

We operationalize the estimate of ESOASSET, by Equation (5), which approximates

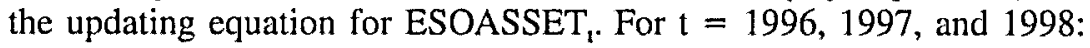

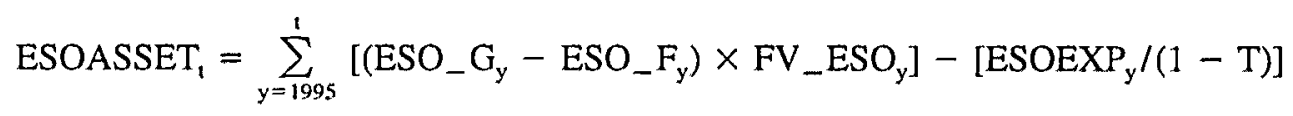

where:

ESO_G $\mathrm{G}_{\mathrm{y}}=$ number of options the employer granted during year $\mathrm{y}$;

ESO_F $F_{y}=$ number of options employees forfeited during year $y$;

$\mathrm{FV}_{-} \mathrm{ESO}_{\mathrm{y}}=$ weighted-average fair value per share for ESOs the employer granted during year $\mathrm{y}$; and

$\mathrm{T}=$ assumed marginal corporate tax rate of 0.35 (all sample firms are profitable in all sample years).

In Equation (5), we measure the fair value of employee stock options granted in year $y$ as ESO_G $\mathrm{G}_{\mathrm{y}}$ multiplied by $\mathrm{FV} \_\mathrm{ESO}_{\mathrm{y}}$ and the before-tax ESO expense as ESOEXP $/ /(1$ - T). The summation in Equation (5) begins in the year 1995 because the SFAS No. 123 ESO expense numbers include the expense of options granted from 1995 and going forward.

Data limitations require that we approximate the other term in Equation (5), the fair value of forfeitures. We would prefer to calculate the fair value of forfeitures by multiplying the number of options employees forfeited by the weighted-average of the fair value per

\footnotetext{
9 This approach is in the spirit of Feltham and Ohlson (1995, Proposition 3). However, the accounting for ESOASSET described in Table 1 implies that ESOASSET should be correlated, but not perfectly correlated, with Options outstanding. Therefore, ESOASSET and Options outstanding will tend to net to zero, in which case an alternative plausible definition of value irrelevance is $\alpha_{4}=0$. Results reported later reveal that ESOASSET is value relevant for most regressions under either definition.

10 However, the Exposure Draft required that the fair value of ESOs granted in year 1 be reduced by estimated forfeitures over the life of the grant, and that actual forfeitures during year $t$ be reduced by estimated forfeitures during year t. Estimated forfeiture numbers are not available to us. Although estimated forfeitures over the life of the grant and the sum of estimated forfeitures in each year of the grant eventually cancel, excluding estimated forfeitures in the updating equation results in an overestimate of ESOASSET,
} 
share of forfeitures. However, we do not have the weighted-average fair value of forfeitures by year. Therefore, we approximate the fair value of forfeitures in any year y by multiplying the number of options employees forfeited during year $y$ by the weighted-average fair value per share for employee stock options granted in year y. This approximation is exact for employee stock options that are granted and forfeited in the same year. To the extent that

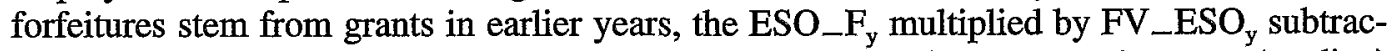
tion in Equation (5) attributable to forfeitures is misestimated. However, the mean (median) ratio of option forfeitures to options outstanding for the firms in our sample is approximately 11 percent ( 7 percent). This suggests that it is unlikely that measurement error in ESOASSET relating to forfeitures will be material. ${ }^{11}$

We estimate cross-sectional regressions for each abnormal earnings equation for 1997 and 1998 and for each valuation equation for 1996, 1997, and 1998, as well as pooled regressions for each equation using year fixed-effects. To minimize the effects of scale differences across sample firms (Barth and Clinch 2001), we estimate all equations after scaling by number of shares outstanding at fiscal year-end. ${ }^{12}$ We report regression t-statistics using White- (1980) corrected standard errors and consider t-statistics with associated twosided p-values less than 0.05 as statistically significant. We do not report constants from pooled fixed-effects regressions.

\section{SAMPLE SELECTION AND DESCRIPTIVE STATISTICS}

Sample firms meet the following data requirements:

1. Listed in software or related service industry on Compustat, SIC Code $=7370$ 7379, as of October 1999.

2. Financial statement and market value data available on Compustat for 1995, 1996, 1997, and 1998.

3. Report positive earnings in 1996, 1997, and 1998.

4. Report nonnegative owner's equity in 1995, 1996, and 1997.

5. Employee stock option data from footnote disclosures mandated under SFAS No. 123 are available from firms' 1996, 1997, and 1998 financial statements.

We adopt the first requirement, which results in a potential sample of 815 firms, because employee stock options are material motivational mechanisms in knowledge-intensive computer software firms. The second requirement, which ensures data availability, reduces the potential sample to 488 firms.

The third requirement, which further reduces the potential sample to 129 firms, constrains the sample to profitable, mature, and stable companies. Unreported diagnostic tests motivated by Hayn (1995) reveal that when we estimate valuation models separately for firms with positive and negative earnings, abnormal earnings have positive and negative coefficients, respectively. The negative coefficient for firms with negative earnings suggests that our valuation model is not specified correctly for such firms. For example, earnings for such firms may be a proxy for other information, such as information about research and development investment, especially for high-growth or start-up companies. Therefore, we restrict our tests to firms with positive earnings where our valuation model is better

11 We also estimated versions of Equations (4a) and (4b) using alternative measures of ESOASSET resulting from different assumptions regarding options exercisable, exercised, and forfeited, including setting forfeitures to zero. Inferences based on these alternative versions essentially are the same as those reported below.

12 In all regressions, we include the inverse of number of shares as a regressor and suppress the intercept, although inferences are unaltered when we include an intercept. In addition, inferences from unscaled and equity book value deflated regressions essentially are the same as those from the reported per share regressions. 
specified. Consequently, the generalizability of our inferences is limited because most computer software firms were unprofitable during the years sampled.

The fourth requirement, which eliminates ten additional firms, constrains the sample to companies with positive beginning owner's equity to ensure that the firm's cost of capital in calculating abnormal earnings $\left(\mathrm{rBVE}_{\mathrm{t}-1}\right)$ is positive. The fifth requirement, which eliminates an another 29 firms, ensures we can obtain ESO data to estimate the accounting variables. Following application of the fifth requirement, we eliminated five more firms with substantially larger total market capitalization relative to the remaining sample. Inferences relating to reported findings are unaffected by inclusion of these five additional firms. The final sample includes 85 software firms that meet the data requirements in 1996, 1997, and 1998, ensuring we estimate valuation and abnormal earnings equations on a common sample of firms.

Annual SFAS No. 123 ESO expenses include amortizations from options granted beginning in 1995. Paragraph 54 of SFAS No. 123 notes that most sample firms require a vesting period of three years or longer. Therefore, the full effects of applying SFAS No. 123 on pro forma net income will not be evident until about 1998. Thus, our ESOEXP and ESOASSET estimates are likely understated in 1996 and 1997, which could affect their regression coefficients in those years. ${ }^{13}$

Table 2's descriptive statistics reveal that, on average, the market value of equity far exceeds the book value of equity for our sample firms. In contrast to prior research on firms drawn from a broad cross-section of industries (Barth et al. 1999, 2000), our sample firms' abnormal earnings are positive, on average. These two findings are likely partially attributable to restricting our sample to firms with positive earnings, but they are also consistent with computer software companies' being high-growth entities. Mean (median) per-share values of ESO expense (ESOEXP) increase over 1996, 1997, and 1998 from 0.09 to 0.15 to 0.24 (0.05 to 0.11 to 0.18 ), respectively, which is consistent with systematic understatement of ESOEXP in the first two years following the statement adoption in 1995 . On average, the ESO asset associated with amortized unvested stock options (ESOASSET) is approximately 7 percent of equity book value.

Table 3 reveals that most of the variables are correlated with each other. Notably, equity market value is highly correlated with: (1) reported equity book value and abnormal earnings, and (2) equity book value and abnormal earnings adjusted to reflect ESO expense.

\section{Benchmark (APB No. 25) Models}

\section{RESULTS}

Panels $\mathrm{A}$ and $\mathrm{B}$ in Table 4 present the benchmark results from estimating abnormal earnings and valuation Equations (1a) and (1b). In Panel A's abnormal earnings forecasting Equation (1a), the coefficient on lagged abnormal earnings $\left(\omega_{1}\right)$ is positive and significant in 1998 and in the pooled estimation. The annual and pooled sample coefficient estimates, which range from 0.31 to 0.47 , are similar to those reported in prior research for samples based on broad cross-sections of firms drawn from many industries (Dechow et al. 1999; Barth et al. 1999). Hence, profitable software firms appear to exhibit persistence in abnormal earnings similar to that for firms in other industries. The coefficient on equity book value $\left(\omega_{3}\right)$ is near zero, which is consistent with prior research (Barth et al. 1999), but, in contrast to prior research, it is insignificant in both years and in the pooled estimation.

Turning to the valuation Equation (1b), Panel B of Table 4 reveals that except for the abnormal earnings coefficient in 1996, the coefficients on abnormal earnings and equity

${ }^{13}$ It is difficult to predict the exact effect of measurement error, absent knowledge of the correlation structure of the measurement error with the variables included in a particular regression. 


\section{TABLE 2}

Descriptive Statistics for Market Value, Book Value, Abnormal Earnings, ESO Expense, and ESO Asset Estimates, for a Sample of 85 Profitable Computer Software Firms

\begin{tabular}{|c|c|c|c|c|c|}
\hline Variable & Year & $n$ & Median & Mean & Std. Dev. \\
\hline \multirow[t]{4}{*}{ MVE } & Pooled & 255 & 19.75 & 23.15 & 14.09 \\
\hline & 1998 & 85 & 24.44 & 27.14 & 16.15 \\
\hline & 1997 & 85 & 21.13 & 23.11 & 12.98 \\
\hline & 1996 & 85 & 16.13 & 19.20 & 11.81 \\
\hline \multirow[t]{4}{*}{ BVE } & Pooled & 255 & 4.44 & 5.03 & 3.13 \\
\hline & 1998 & 85 & 5.33 & 5.82 & 3.26 \\
\hline & 1997 & 85 & 4.28 & 5.02 & 3.09 \\
\hline & 1996 & 85 & 3.70 & 4.26 & 2.86 \\
\hline \multirow[t]{4}{*}{ BVE_ADJ } & Pooled & 255 & 4.22 & 4.74 & 3.08 \\
\hline & 1998 & 85 & 4.77 & 5.33 & 3.24 \\
\hline & 1997 & 85 & 4.00 & 4.75 & 3.06 \\
\hline & 1996 & 85 & 3.52 & 4.13 & 2.84 \\
\hline \multirow[t]{4}{*}{ AEARN } & Pooled & 255 & 0.18 & 0.20 & 0.42 \\
\hline & 1998 & 85 & 0.21 & 0.22 & 0.47 \\
\hline & 1997 & 85 & 0.20 & 0.19 & 0.40 \\
\hline & 1996 & 85 & 0.16 & 0.20 & 0.40 \\
\hline \multirow[t]{4}{*}{ AEARNESO } & Pooled & 255 & 0.08 & 0.06 & 0.46 \\
\hline & 1998 & 85 & 0.01 & 0.00 & 0.52 \\
\hline & 1997 & 85 & 0.09 & 0.05 & 0.41 \\
\hline & 1996 & 85 & 0.08 & 0.11 & 0.43 \\
\hline \multirow[t]{4}{*}{ ESOEXP } & Pooled & 255 & 0.10 & 0.16 & 0.18 \\
\hline & 1998 & 85 & 0.18 & 0.24 & 0.23 \\
\hline & 1997 & 85 & 0.11 & 0.15 & 0.15 \\
\hline & 1996 & 85 & 0.05 & 0.09 & 0.11 \\
\hline \multirow[t]{4}{*}{ ESOASSET } & Pooled & 255 & 0.25 & 0.37 & 0.44 \\
\hline & 1998 & 85 & 0.26 & 0.49 & 0.54 \\
\hline & 1997 & 85 & 0.26 & 0.39 & 0.43 \\
\hline & 1996 & 85 & 0.13 & 0.24 & 0.28 \\
\hline
\end{tabular}

\footnotetext{
Variable definitions (we deflate to a per-share basis by dividing by number of shares outstanding at fiscal yearend):

MVE = market value of common shares outstanding at fiscal year-end;

$\mathrm{BVE}=$ book value of common equity as of fiscal year-end;

BVE_ADJ = BVE minus ESOEXP accumulated since 1995;

AEARN $=$ abnormal earnings measured as net income before extraordinary items and discontinued operations, minus $0.12 \times$ BVE (lagged one year);

AEARNESO = abnormal earnings after ESO expense measured as net income before extraordinary items and discontinued operations, minus ESOEXP, minus $0.12 \times$ BVE_ADJ (lagged one year);

ESOEXP $=$ ESO expense measured as reported net income minus pro forma net income per SFAS No. 123 disclosure; and

ESOASSET $=$ ESO asset associated with unvested employee stock options as of fiscal year-end. ESOASSET corresponds to the Exposure Draft's asset Prepaid compensation calculated from Equation (5).
} 


\section{TABLE 3}

Pearson Correlations among Variables: Market Value, Book Value, Abnormal Earnings, ESO Expense, and ESO Asset Estimates

Variable

$$
\underline{M V E} \quad \underline{B V E} \quad \underline{B V E-A D J}
$$

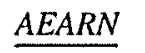

AEARNESO

ESOEXP

ESOASSET

Panel A: Pooled across Years $(n=255)$

$\begin{array}{lll}\text { MVE } & 1.00 & \\ \text { BVE } & 0.49 & 1.00\end{array}$

$\begin{array}{lll}\text { BVE_ADJ } & 0.46 & 0.99\end{array}$

$\begin{array}{lll}\text { AEARN } & 0.42 & 0.14\end{array}$

AEARNESO $\quad 0.27 \quad 0.09$

$\begin{array}{lll}\text { ESOEXP } & 0.32 & 0.14\end{array}$

ESOASSET

$0.30 \quad 0.01$

1.00

0.15

1.00

0.13

0.94

1.00

0.04

$-0.02$

$-0.37$

$-0.03$

0.03

$-0.12$

1.00

0.41

Panel B: $1998(n=85)$

MVE $\quad 1.00$

$\begin{array}{lll}\text { BVE } & 0.48 & 1.00\end{array}$

$\begin{array}{llll}\text { BVE_ADJ } & 0.45 & 0.99 & 1.00\end{array}$

$\begin{array}{llll}\text { AEARN } & 0.38 & 0.02 & 0.03\end{array}$

$\begin{array}{llll}\text { AEARNESO } & 0.22 & 0.01 & 0.06\end{array}$

$\begin{array}{llll}\text { ESOEXP } & 0.28 & 0.05 & -0.08\end{array}$

$\begin{array}{llll}\text { ESOASSET } & 0.24 & -0.10 & -0.14\end{array}$

$\begin{array}{rr}1.00 & \\ 0.92 & 1.00 \\ -0.07 & -0.45 \\ 0.02 & -0.14\end{array}$

1.00

0.38

1.00

Panel C: $1997(n=85)$

MVE $\quad 1.00$

$\begin{array}{lll}\text { BVE } & 0.45 & 1.00\end{array}$

BVE_ADJ $\quad 0.43 \quad 1.00$

$\begin{array}{llll}\text { AEARN } & 0.47 & 0.09 & 0.09\end{array}$

$\begin{array}{llll}\text { AEARNESO } & 0.37 & 0.05 & 0.07\end{array}$

$\begin{array}{llll}\text { ESOEXP } & 0.26 & 0.13 & 0.04\end{array}$

ESOASSET

$0.18-0.04$

$-0.07$

$\begin{array}{rr}1.00 & \\ 0.94 & 1.00 \\ 0.08 & -0.25 \\ -0.01 & -0.11\end{array}$

1.00

0.31

1.00

Panel D: $1996(n=85)$

$\begin{array}{llll}\text { MVE } & 1.00 & & \\ \text { BVE } & 0.45 & 1.00 & \\ \text { BVE_ADJ } & 0.44 & 1.00 & 1.00 \\ \text { AEARN } & 0.45 & 0.37 & 0.37 \\ \text { AEARNESO } & 0.36 & 0.33 & 0.35 \\ \text { ESOEXP } & 0.24 & 0.09 & 0.03 \\ \text { ESOASSET } & 0.47 & 0.08 & 0.06\end{array}$

1.00

$0.37 \quad 1.00$

$\begin{array}{ll}0.35 & 0.97\end{array}$

$0.03-0.07$

$0.06 \quad 0.08$

1.00
-0.32
-0.03

1.00

0.41

1.00

a See Table 2 for definitions of variables.

book value are significantly positive in the pooled sample and across all years. The abnormal earnings coefficients, which range from 9.07 to 16.28 , are somewhat higher than those reported in Barth et al. (1999) for firms in most other industries, which is somewhat unexpected given that autoregressive persistence parameters $\left(\omega_{1}\right)$ for our sample firms' abnormal earnings are similar to those reported in Barth et al. (1999). 


\section{TABLE 4}

Regressions of Abnormal Earnings and Equity Market Value Based on APB No. 25 Accounting for Stock-Based Compensation Expense, for 85 Profitable Software Firms $^{\mathrm{a}}$

\begin{tabular}{|c|c|c|c|c|c|c|c|c|}
\hline \multirow[b]{2}{*}{ Year } & \multirow[b]{2}{*}{$n$} & \multicolumn{2}{|c|}{ CONSTANT } & \multicolumn{2}{|c|}{$A E A R N$} & \multicolumn{2}{|c|}{$B V E$} & Model \\
\hline & & Coefficient & $\begin{array}{c}\text { White } \\
\text { t-statistic }\end{array}$ & Coefficient & $\begin{array}{c}\text { White } \\
t \text {-statistic }\end{array}$ & Coefficient & $\begin{array}{c}\text { White } \\
\text { t-statistic }\end{array}$ & $\begin{array}{c}\text { Adjusted } \\
R^{2}\end{array}$ \\
\hline
\end{tabular}

Panel A: Abnormal Earnings Equation

\begin{tabular}{|c|c|c|c|c|c|c|c|c|}
\hline \multirow[b]{2}{*}{ Pooled } & \multicolumn{8}{|c|}{$A E A R N_{i t}=\omega_{0}+\omega_{1} A E A R N_{i, t-1}+\omega_{3} B V E_{i, t-1}+\varepsilon_{i t}^{A}$} \\
\hline & 170 & - & - & 0.39 & 2.66 & 0.02 & 1.69 & 0.203 \\
\hline 1998 & 85 & -0.55 & -1.15 & 0.47 & 2.99 & 0.02 & 1.09 & 0.221 \\
\hline 1997 & 85 & -0.11 & -0.28 & 0.31 & 1.31 & 0.02 & 1.55 & 0.179 \\
\hline
\end{tabular}

Panel B: Valuation Equation

$$
M V E_{i t}=\alpha_{0}+\alpha_{1} A E A R N_{i t}+\varepsilon_{3} B V E_{i t}+\varepsilon_{i t}^{M}
$$

$\begin{array}{lrrrrrrrr}\text { Pooled } & 255 & - & - & 13.12 & 5.25 & 3.58 & 21.57 & 0.780 \\ 1998 & 85 & -21.05 & -1.91 & 14.25 & 4.55 & 3.87 & 12.86 & 0.809 \\ 1997 & 85 & -10.18 & -1.16 & 16.28 & 5.17 & 3.45 & 14.02 & 0.797 \\ 1996 & 85 & -0.83 & -0.11 & 9.07 & 1.81 & 3.26 & 12.56 & 0.720\end{array}$

a See Table 2 for definitions of all variables except CONSTANT.

Estimates for all equations are in per-share form with intercepts surpressed.

Included in the scaled models is the regressor CONSTANT (the inverse of number of shares outstanding at fiscal year-end) to estimate the intercept for the corresponding unscaled models.

CONSTANT coefficients and associated t-statistics for pooled fixed-effects regressions are not reported.

The coefficients on common shareholders' equity book value range from 3.26 to 3.87 . Untabulated test statistics reveal that these coefficients significantly exceed 1.00. Absent accounting conservatism, the Ohlson (1995) model predicts the equity book value coefficient to equal 1.00. Conservative accounting results in systematic understatement of equity book value and, hence, systematic overstatement of its valuation coefficient.

\section{SFAS No. 123 Models}

Panels $\mathrm{A}$ and $\mathrm{B}$ in Table 5 present the results of estimating the abnormal earnings forecasting and valuation Equations (2a) and (2b) under the SFAS No. 123 approach, which requires disclosure of ESO-related compensation expense but not an ESO-related asset. Regarding Equation (2a), Panel A reveals that the coefficient on lagged abnormal earnings adjusted for employee stock option expense $\left(\omega_{1}\right)$ is positive and once again significant in 1998 and in the pooled estimation. The annual and pooled sample coefficient estimates range from 0.35 to 0.46 , which are similar to those reported for unadjusted abnormal earnings in Table 4. As with unadjusted equity book value in Table 4, the coefficient estimates for adjusted equity book value $\left(\omega_{3}\right)$ are near zero and insignificant. The notable difference between Table 4, Panel A, and Table 5, Panel A, is that the abnormal earnings forecasting model explanatory power drops by approximately 40 percent when we adjust abnormal earnings and equity book value for ESO expense. Although we cannot directly compare $\mathrm{R}^{2}$ values because dependent variables differ across the two tables, the drop in explanatory power is nonetheless consistent with ESO expense having a different abnormal 


\section{TABLE 5}

Regressions of Abnormal Earnings and Equity Market Value Based on SFAS No. 123 Accounting for Stock-Based Compensation Expense Recognition Rules, for 85 Profitable Software Firms ${ }^{a}$

\begin{tabular}{|c|c|c|c|c|c|c|c|c|}
\hline \multirow[b]{2}{*}{ Year } & \multirow[b]{2}{*}{$n$} & \multicolumn{2}{|c|}{ CONSTANT } & \multicolumn{2}{|c|}{ AEARNESO } & \multicolumn{2}{|c|}{$B V E \_A D J$} & Mo \\
\hline & & Coefficient & $\begin{array}{c}\text { White } \\
\text { t-statistic }\end{array}$ & Coefficient & $\begin{array}{c}\text { White } \\
\text { t-statistic }\end{array}$ & Coefficient & $\begin{array}{c}\text { White } \\
\text { t-statistic }\end{array}$ & $\begin{array}{c}\text { Adjusted } \\
R^{2}\end{array}$ \\
\hline
\end{tabular}

Panel A: Abnormal Earnings Equation

$$
\text { AEARNESO }_{i t}=\omega_{0}+\omega_{1} \text { AEARNESO }_{i, t-1}+\omega_{3} B V E_{-} A D J_{i, t-1}+\varepsilon_{i t}^{A}
$$

$\begin{array}{lrlllllll}\text { Pooled } & 170 & - & - & 0.41 & 2.88 & -0.00 & -0.28 & 0.124 \\ 1998 & 85 & -0.67 & -1.32 & 0.46 & 2.64 & -0.00 & -0.20 & 0.128 \\ 1997 & 85 & -0.23 & -0.61 & 0.35 & 1.69 & -0.00 & -0.12 & 0.108\end{array}$

Panel B: Valuation Equation

$$
M V E_{i t}=\alpha_{0}+\alpha_{1} A E A R N E S O_{i t}+\alpha_{3} B V E_{-} A D J_{i t}+\varepsilon_{i t}^{M}
$$

\begin{tabular}{|c|c|c|c|c|c|c|c|c|}
\hline Pooled & 255 & - & - & 5.47 & 2.09 & 4.11 & 20.00 & 0.724 \\
\hline 1998 & 85 & -24.85 & -1.82 & 4.44 & 1.03 & 4.52 & 12.13 & 0.738 \\
\hline 1997 & 85 & -8.57 & -0.95 & 10.47 & 2.99 & 3.95 & 12.87 & 0.743 \\
\hline 1996 & 85 & -2.38 & -0.31 & 4.05 & 0.99 & 3.63 & 12.10 & 0.692 \\
\hline
\end{tabular}

"See Table 2 for definitions of all variables except CONSTANT.

Estimates for all equations are in per-share form with intercepts surpressed.

Included in the scaled models is the regressor CONSTANT (the inverse of number of shares outstanding at fiscal year-end) to estimate the intercept for the corresponding unscaled models.

CONSTANT coefficients and asscociated t-statistics for pooled fixed-effects regressions are not reported.

earnings persistence parameter from the other earnings components. That is, adjusting equity book value and abnormal earnings for ESO expense in Panel A of Table 5, without permitting ESO expense to have a different total coefficient from other expense components of income, induces model misspecification. Alternatively, the drop in explanatory power could also be attributable to measurement error in the adjusted abnormal earnings and equity book value variables, induced by noisy ESO adjustments.

Turning to the valuation Equation (2b), Panel B of Table 5 reveals that the coefficients on adjusted abnormal earnings are positive in all estimations, but significant only in 1997 and for the pooled sample. The coefficients on adjusted equity book value are significantly positive in the pooled sample and across all years. The AEARNESO valuation coefficients and model explanatory power for Panel B are lower in Table 5 than in Table 4. Again, the drop in explanatory power, which is significant, is consistent with either investors' assessing ESO expense differently from other expenses, or with ESO adjustments inducing measurement error in accounting variables. ${ }^{14}$ Tables 6 and 7, in which we permit ESO expense to

14 We determine whether model explanatory power differs between the two non-nested valuation Equations (1b) and (2b) using the Vuong (1989) likelihood ratio test, which permits comparison of explanatory power of two alternative models without assuming under the null that either model is the correct model. The explanatory power for Equation (1b) is significantly higher than that of Equation (2b) at less than the 0.01 level in 1997, 1998 , and for the pooled sample, and at the 0.05 level in 1996. 
have a separate coefficient, provide evidence on which interpretation is more descriptively valid.

To assess incremental effects of ESO expense (ESOEXP) in the forecasting and valuation equations, Panels $\mathrm{A}$ and $\mathrm{B}$ in Table 6 present the results of estimating the abnormal earnings and valuation Equations (3a) and ( $3 b)$, which permit ESOEXP to have different coefficients from adjusted abnormal earnings. Panel $A$ indicates that ESOEXP has predictive ability for the next period AEARNESO. In particular, the total coefficient on ESOEXP $\left(-\omega_{1}+\omega_{2}\right)$ is significantly negative in 1998 and for the pooled sample, indicating that higher current ESO expenses predict lower future abnormal earnings.

Panel B of Table 6 reveals strong evidence that ESOEXP is value-relevant. The coefficients on ESOEXP range from 43.61 to 54.48 and are significant in all three years and for the pooled sample, indicating that investors value ESOEXP significantly differently from other earnings components. Moreover, the total ESOEXP coefficient $\left(-\alpha_{1}+\alpha_{2}\right)$ is significantly positive in all three years and for the pooled sample, which is consistent with investors viewing ESOEXP as an asset rather than an expense.

The abnormal earnings equation results in Panel A of Table 6 suggest that the ESOEXP valuation coefficient should be negative, not positive. The Ohlson (1995) model predicts that if higher ESOEXP leads to lower future abnormal earnings, then the market should value ESOEXP negatively. One explanation for finding that ESOEXP has a positive coefficient in the valuation equation and a negative coefficient in the abnormal earnings forecasting equation is that our models omit an intangible asset (ESOASSET) that is associated with issuance of employee stock options. Thus, we now investigate whether investors still appear to value ESOEXP positively even after we control for the ESOASSET using the Exposure Draft model approach.

\section{Exposure Draft Models}

In Table 7, Panels A and B present results of estimating the abnormal earnings and valuation Equations (4a) and (4b) under the Exposure Draft approach, which allows the total ESOEXP coefficients to differ from those on adjusted abnormal earnings and also includes ESOASSET, an estimate of the ESO asset measured as amortized fair value of unvested employee stock options. Panel A reveals that including ESOASSET does not help predict abnormal earnings and that its inclusion has little effect on the full ESOEXP coefficient in the abnormal earnings regression $\left(-\omega_{1}+\omega_{2}\right)$. As in Panel A for Table 6, ESOEXP is significantly negatively associated with next year's adjusted abnormal earnings, in 1998 and for the pooled sample.

Turning to the valuation Equation (4b), as in Panel B for Table 6, the incremental coefficient on ESOEXP is significantly positive. Relative to Table 6, the incremental ESOEXP coefficient drops by approximately one-third when we include ESOASSET. The total ESOEXP coefficient $\left(-\alpha_{1}+\alpha_{2}\right)$ is significantly positive; therefore, ESOEXP is valuerelevant. Regarding ESOASSET, its incremental coefficient is significantly positive, ranging from 7.11 to 19.97 , and tests confirm that the total coefficient $\left(\alpha_{3}+\alpha_{4}\right)$ is significantly positive, so ESOASSET is also value-relevant. These results are consistent with investors' not only valuing ESOASSET as a firm asset, but also with their valuing ESOASSET more highly than other net assets. This finding also supports Stewart's (1997) view that employee stock options create an intangible asset-a form of intellectual capital.

\section{Do Investors Positively Value ESO Expense Even Though It Is Negatively Related to Next Period's Abnormal Earnings?}

The evidence in Table 7 that investors positively value ESOEXP even though ESOEXP is negatively related to future abnormal earnings is contrary to theory (Ohlson 1999, 151). 


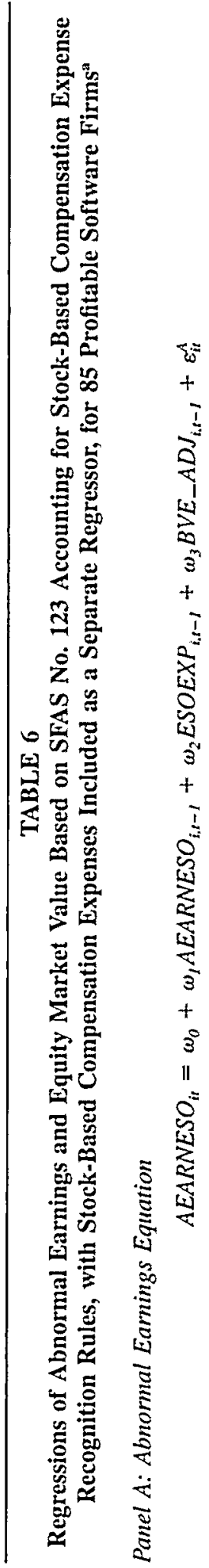

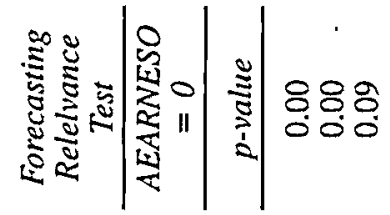
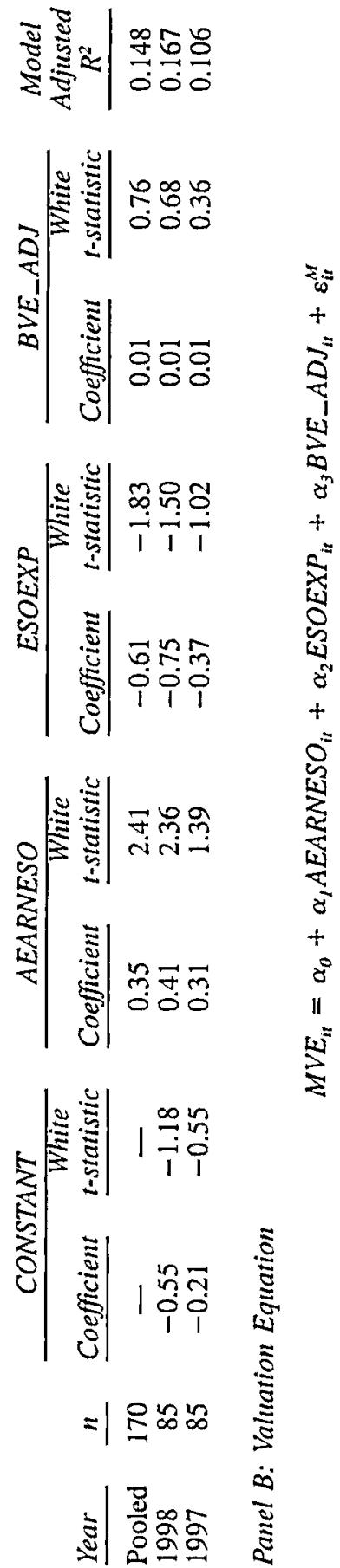

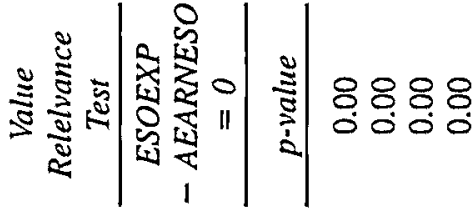

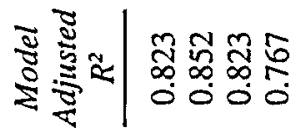
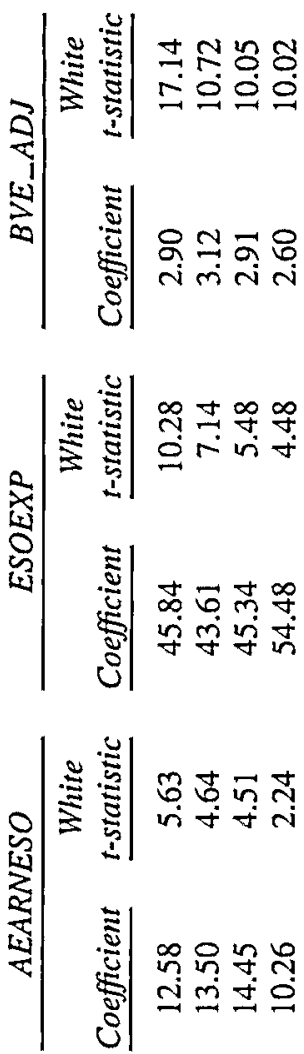

总

总

实

安总总

突它

8

믕

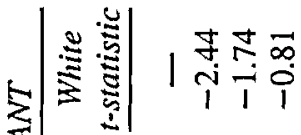

远 응

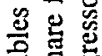

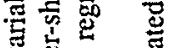

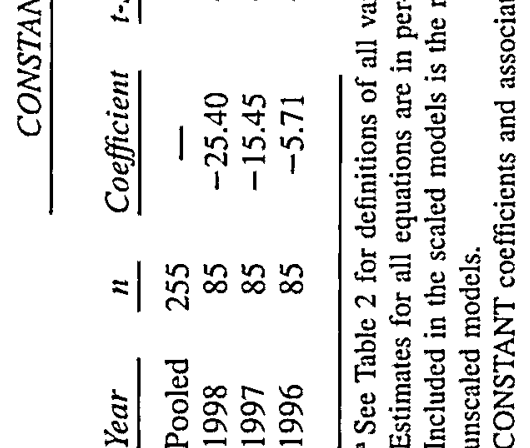




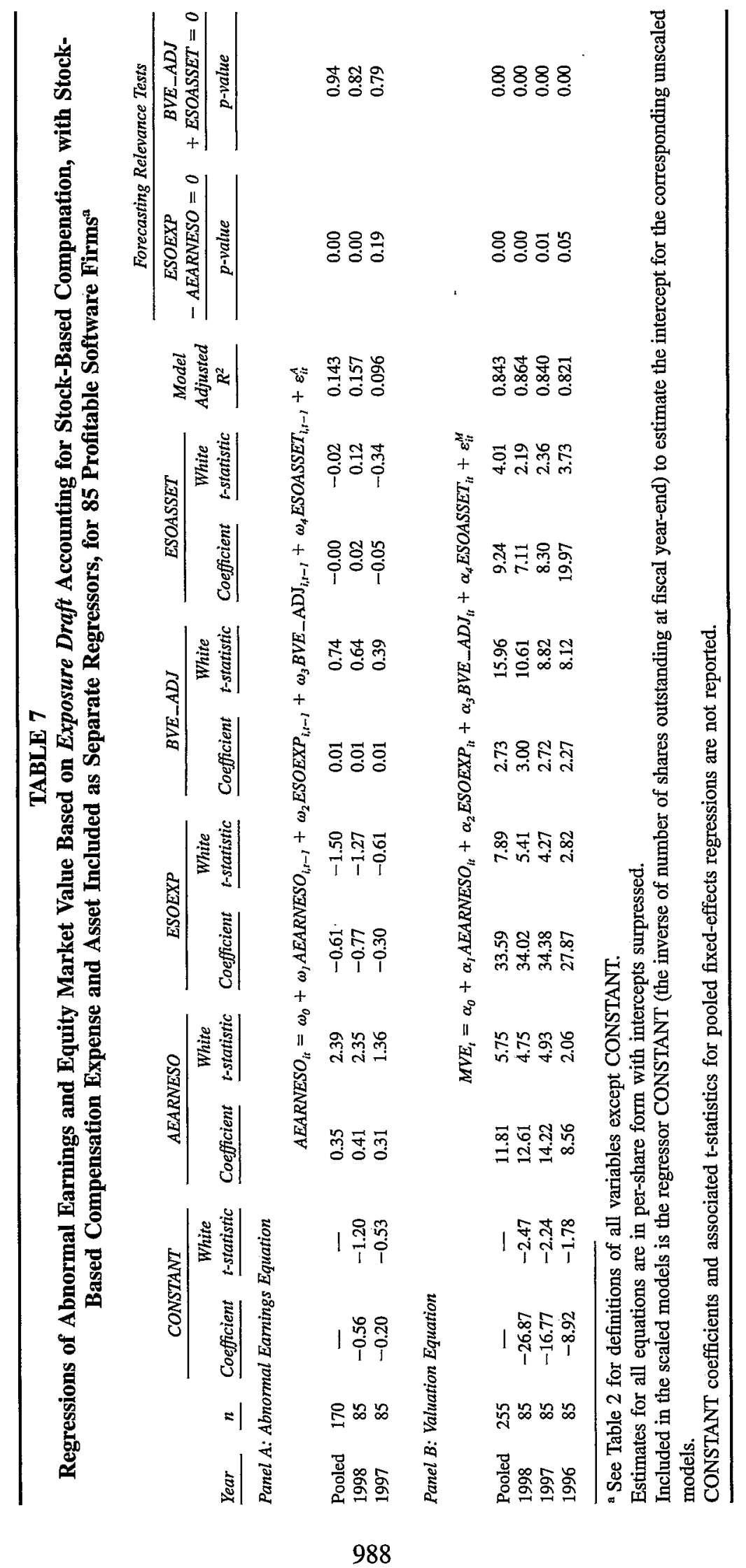


Why is the total ESOEXP coefficient negative in the abnormal earnings forecasting models, and yet positive in the valuation models? Either our empirical models are misspecified, or investors do not correctly assess the effect of ESO expense on profitable software firms' value. We consider each in turn.

One explanation is that our first-order autoregressive model of abnormal earnings is not descriptively valid. ${ }^{15}$ For example, employee stock options may create value that does not manifest in earnings until two or more years in the future, but the single-period lag structure in our autoregressive abnormal earnings forecasting equation does not capture this effect. Unfortunately, we cannot improve the specification of the abnormal earnings forecasting equation by extending the lag structure beyond a single period, because our sample spans only three years.

A second explanation for the unexpectedly positive values of ESOEXP's total coefficients in the valuation equations is that the amortized ESO asset does not fully capture the effect of the intangible asset on firm value. Thus, we consider an alternative measure of ESOASSET in an attempt to improve the specification of the valuation equation.

The evidence in Panel B of Table 7 that ESOEXP's total coefficient remains positive even after we include ESOASSET in the valuation equation, suggests that our measure of the ESO intangible asset ESOASSET does not fully capture the valuation effect of the intangible asset. We consider an alternative measure, the gross (unamortized) ESO asset, ESOASSET_G, which equals ESOASSET plus before-tax accumulated amortization measured as pre-tax ESOEXP cumulated since 1995. This alternative measure represents the extreme view that employee stock options create an intangible asset that has an infinite useful life. Panel $A$ in Table 8 presents results of estimating the valuation Equation (4b) using ESOASSET_G as the measure of the ESO asset. Because the ESO asset is unamortized, there is no ESO expense. Thus, we include AEARN instead of AEARNESO, and $B V E$ instead of BVE_ADJ. We also include ESOEXP in the estimating equation, even though there is no ESO expense when the ESO asset is not amortized. If the unamortized ESO asset measures the intangible ESO asset with less error than does its amortized counterpart, then ESOEXP may no longer be value-relevant when we include ESOASSET_G rather than ESOASSET in the valuation equation. The Ohlson (1995) model permits us to include ESOEXP with ESOASSET_G by viewing ESOEXP as "other information."

As with ESOASSET in Panel B of Table 7, the incremental coefficient estimates on ESOASSET_G are positive and significant (although marginally so in 1997), ranging from 7.09 to 24.99 , and tests confirm ESOASSET_G is value-relevant. The key distinction is that in all estimations, $\alpha_{2}$, the coefficient on employee stock option expense (ESOEXP) is not significantly positive (in fact, it is negative in 1996). These findings are consistent with investors valuing the ESO asset as if it had an infinite life. Consistent with the intellectual capital perspective, the results suggest that the asset created at grant date has a useful life in excess of the option-vesting period.

A third explanation for finding negative values for the total ESOEXP coefficient in the abnormal earnings forecasting model, and positive coefficients in the valuation models, questions whether investors in profitable computer software companies correctly assess the effect of employee stock options on firm value. Although we favor the modelmisspecification interpretation for the different ESOEXP coefficients, we are unable to rule out the market-inefficiency interpretation based on our tests.

is Barth et al. $(1999,221)$ make a similar observation in the context of the valuation implications of accruals and cash flows. 


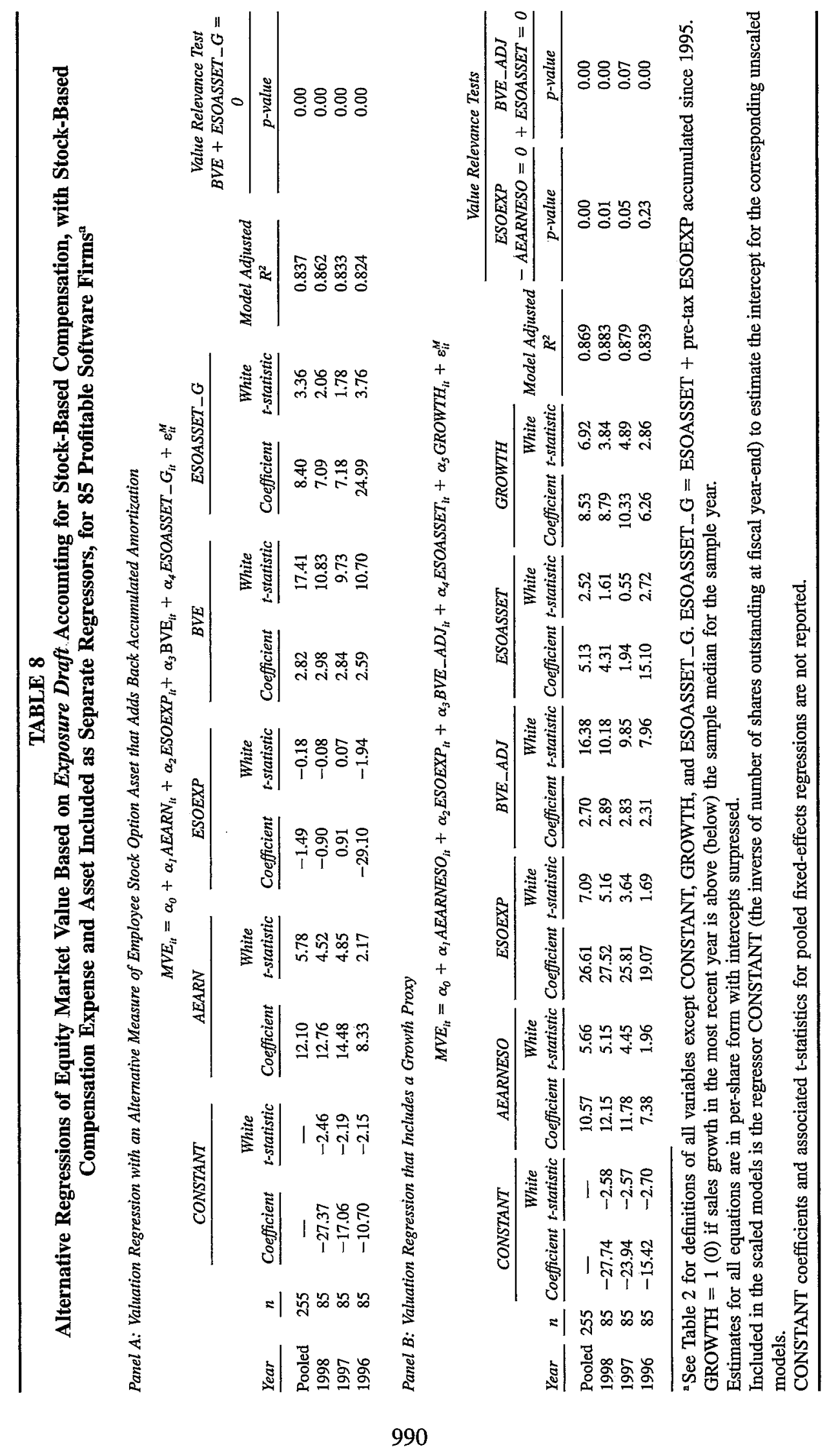




\section{Growth}

\section{ADDITIONAL ANALYSES}

The findings reported in Panel B of Table 7 indicate that ESOASSET is value-relevant. If its value-relevance is attributable to capturing the growth potential in future cash flows arising from contributed intellectual capital, then controlling for an alternative measure of growth in the valuation equation should reduce the value-relevance of the ESO intangible asset (see Barth et al. 2001, 96-97). If ESOASSET retains explanatory power after controlling for the alternative growth measure, then it reflects value-possibly arising from contributed intellectual capital - beyond that reflected in the additional growth measure.

We re-estimate the valuation Equation (4b) after including an indicator variable equal to $1(0)$ if sales growth in the most recent year is above (below) the median for our sample firms in that year. Panel $\mathrm{B}$ in Table 8 indicates that investors significantly value the growth proxy. In addition, its inclusion reduces the incremental coefficient on ESOASSET to insignificant levels in 1997 and 1998, which suggests that ESOASSET reflects future sales growth potential. However, the total coefficient on ESOASSET $\left(\alpha_{3}+\alpha_{4}\right)$, remains positive and significant except in 1997, indicating ESOASSET does reflect dimensions of value beyond sales growth, perhaps growth in expected future cash flows arising from employees' contributed intellectual capital.

\section{Elimination of Price Endogeneity Bias}

Aboody (1996) notes that because ESO values increase with prices of underlying stocks, regressing stock prices on ESO values creates an endogeneity problem. We use two different approaches to ensure that our finding that investors positively value ESOASSET is not merely an artifact of this endogeneity bias. First, we replace ESOASSET with an instrument that is uncontaminated by the firm's stock price-the number of unvested employee stock options (UNVESTED_ESO). We determine UNVESTED_ESO's valuerelevance using its incremental coefficient, because the number of unvested employee stock options cannot be a component of equity book value. Second, we adopt a two-stage instrumental variable approach following Aboody et al. (2001) and Chamberlain and Hseih (1999). The two-stage procedure purges ESO expense of endogeneity bias by regressing ESO expense on various disclosed option-pricing model inputs, the vesting period, and the number of options granted, and then replacing ESO expense with the fitted value from the first-stage regression in their second-stage valuation regression. We follow this same procedure by replacing ESOEXP with its fitted (or predicted) value ESOEXP_PRD and ESOASSET with ESOASSET_PRD, which we estimate in a similar way to ESOEXP_ PRD. ${ }^{16}$ We include AEARN instead of AEARNESO and BVE instead of BVE_ADJ because we do not adjust abnormal earnings and equity book value for the predicted ESO expense (which is, of course, not a disclosed amount). Thus, we determine value-relevance for ESOEXP_PRD and ESOASSET_PRD using their incremental coefficients, $\alpha_{2}$ and $\alpha_{4}$.

Table 9 reports the results of estimating the valuation Equation (4b) regressions incorporating the two approaches to eliminate endogeneity bias. These results reveal that we cannot attribute the positive valuation of ESOASSET to endogeneity bias. In particular, the incremental coefficients on the number of unvested employee stock options

\footnotetext{
16. The first-stage regression includes an estimate of the firm's stock price volatility, expected option life, the riskfree rate, dividend yield, and the number of unvested options outstanding. Aboody et al. (2001) use the number of options granted instead of the number of unvested options outstanding. Unreported findings reveal that using the number of options granted does not affect our inferences.
} 


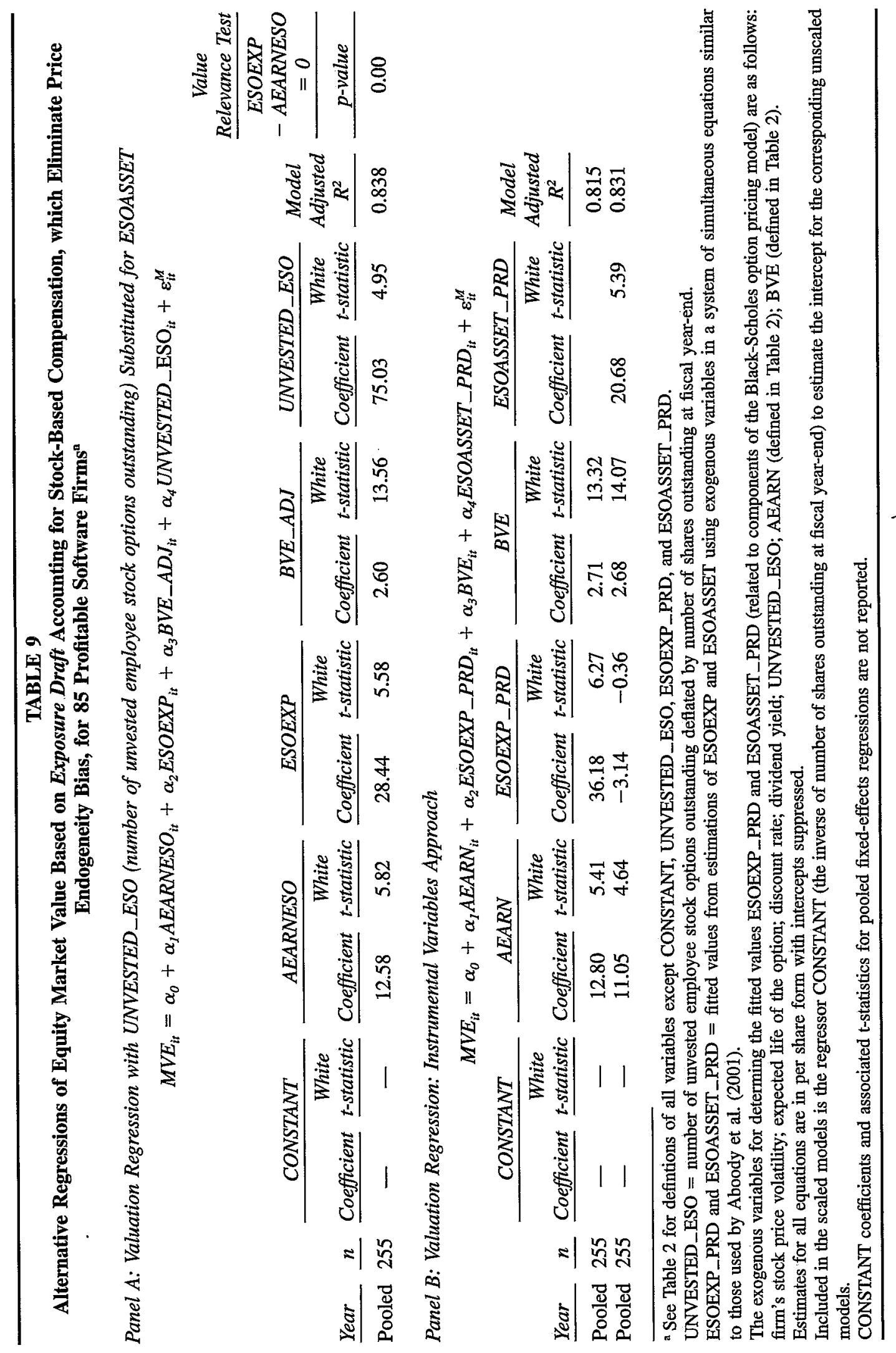


(UNVESTED_ESO) and the predicted ESO asset (ESOASSET_PRD) are significantly positive. ${ }^{17}$ Notably, in contrast to Aboody et al. (2001) and Chamberlain and Hseih (1999), who find a negative relation between equity market value and predicted ESO expense, Panel $B$ reveals that the valuation coefficient on the ESO expense variable (ESOEXP_PRD), $\alpha_{2}$, remains significantly positive when the ESO asset variable (ESOASSET_PRD) is omitted from the estimating equation. However, when ESOASSET_PRD is included in the estimating equation, the ESOEXP_PRD coefficient $\left(\alpha_{2}\right)$ is insignificantly different from zero.

Differences between our findings and those of Aboody et al. (2001) and Chamberlain and Hseih (1999) are most likely attributable to sample differences. In particular, sample firms in the other two studies represent a broader set of industries and are not necessarily profitable. Employee stock options may very well create a valuable intangible asset for profitable firms in knowledge-intensive industries, but not for firms in other industries. For example, Keating et al. (2002) estimate valuation models for Internet firms in the period surrounding the Internet downturn in the first quarter of 2000 . They find that their measure of the fair value of employee stock options granted in 1999 is significantly positively associated with equity value, consistent with our finding that the ESO asset is positively associated with share prices. However, their estimate of employee stock options granted in 1999 is neither a book value variable nor an earnings variable but rather a value-relevant variable outside the accounting system.

\section{ESO Valuation vs. SG\&A Valuation}

The evidence in Panel $B$ of Table 7 that investors value ESO expenses (ESOEXP) positively even when the valuation model includes a measure of the intangible asset (ESOASSET) raises the question of whether other compensation creates intangible value for the firm. Ideally, we would test this proposition by estimating the valuation of compensation expense. However, because we do not have access to compensation expense data, we instead use selling, general, and administrative expense (SG\&A), which is a noisy proxy for compensation expense. First, it excludes salaries embedded in the cost of goods sold. Second, SG\&A includes costs that are not entirely compensation, such as advertising expense and research and development expense, each of which reflects priced but unrecorded intangible assets related to innovative activities (Landsman and Shapiro 1995; Aboody and Lev 1998; Hall 1999; Hall et al. 1999). The effect of these noncompensation costs should bias toward finding a positive valuation effect for SG\&A.

To test the proposition that investors value SG\&A differently from other components of AEARNESO, we estimate Equation (4b) including SG\&A as a separate regressor, which permits SG\&A to have a pricing effect different from AEARNESO. Untabulated findings indicate that the incremental SG\&A coefficient is not significantly different from zero, indicating that it is not valued differently from other expense components of income. In addition, including SG\&A does not affect inferences relating to ESOEXP and ESOASSET.

\footnotetext{
${ }^{17}$ Finding a positive pricing coefficient on the number of unvested options does not imply that firms can increase their stock prices simply by issuing stock options. Aboody (1996) and our own unreported analyses from a regression in which we substitute the number of vested options (VESTED_ESO) in place of ESOASSET in Equation (4b) yield a negative coefficient on VESTED_ESO. This is consistent with the value to the firm of the intangible capital provided by the vested options being smaller than their diluting effect on ownership value for present common shareholders.
} 
Most significantly, in contrast to SG\&A, ESOEXP still has a positive incremental association with equity value. ${ }^{18}$ Thus, our results suggest that for profitable software firms, investors value ESO expense differently from other components of income, and differently from other forms of compensation as reflected in SG\&A.

\section{Alternative Definition of Computer Software Firms}

A final robustness test estimates Equations (4a) and (4b) using a narrower definition of profitable computer software firms. In their paper on the value-relevance of software capitalization, Aboody and Lev (1998) include firms from SIC codes 7370 to 7372 . Limiting our sample to these three codes could produce a more powerful test of whether investors value ESOASSET as an intangible asset-if intellectual capital is a larger component of these "purer" software firms-although this restriction reduces our annual sample to 66 firms. Untabulated results are similar to those reported for the full sample of 85 firms.

\section{SUMMARY AND CONCLUSIONS}

This paper compares the extent to which the accounting methods specified by APB No. 25, SFAS No. 123, and the Exposure Draft reflect the market's assessment of the effects of employee stock options (ESOs) on firm value, using the Feltham and Ohlson (1999) valuation model for a sample of 85 profitable computer software firms. For each method we estimate abnormal earnings and valuation equations. The fundamental question we address is whether investors view profitable software firms' ESO expenses similarly to other expenses.

Findings from estimating equations under the SFAS No. 123 approach (which requires only disclosure of the ESO expense) indicate that similar to other expenses, current ESO expense forecasts lower abnormal earnings in the subsequent year. However, contrary to the Ohlson (1999) model's prediction given a negative relation between current ESO expense and future abnormal earnings, investors appear to value ESO expense as an asset. One explanation is that the SFAS No. 123 models omit an intangible asset. Findings from estimating equations under the Exposure Draft approach (which would have required recognition of an ESO asset as well as an ESO expense) suggests that investors perceive the ESO asset as value-relevant. In addition, our results suggest that investors value this asset more highly than they do other net assets of the firm, which is consistent with employee stock options creating a valuable intangible asset (i.e., contributed intellectual capital). Interestingly, our results suggest that investors continue to value ESO expense as an asset even when we include the amortized ESO asset in the valuation model. This result suggests that the amortized ESO asset may not capture fully the future net economic benefit of employee stock options. When we repeat this analysis using the unamortized (gross) ESO asset, the ESO asset remains value-relevant while ESO expense does not, which is consistent with the market expecting the ESO asset to have a useful life longer than the option-vesting period.

We interpret our results based on the market-efficiency assumption. However, we find a conflict between the positive manner in which investors value ESO expense vs. the negative relation between ESO expense and future abnormal earnings. This finding calls into question whether investors in profitable software companies assess the effect of employee

${ }_{18}$ We also estimated Equation (4a) including SG\&A as a separate regressor. As with the valuation equation, untabulated findings indicate that SG\&A has a negative total coefficient, significant in 1997 and for the pooled sample. 
stock options correctly. Another explanation is that our simple first-order autoregressive structure for abnormal earnings is not descriptively valid for ESO expense. We also interpret the study's results assuming that we measure the ESO accounting variables without error, even though firms understate ESO expense in our first two sample years.

Taken together, we interpret our study's findings as suggesting that the Exposure Draft approach to accounting for stock options best captures the market's perception of the economic effect of employee stock options on profitable computer software firm value. Most notably, the results suggest that investors in profitable software companies perceive that employee stock options create an intangible asset that they value more highly than other assets of the firm. This is consistent with employee stock options playing an important role in employee attraction, motivation, and retention (Ittner et al. 2002) in knowledge-intensive industries. We leave it to future research to determine the extent to which our findings generalize to firms in other industries or to nonprofitable entities.

\section{REFERENCES}

Aboody, D. 1996. Market valuation of employee stock options. Journal of Accounting and Economics 22 (August-December): 357-391.

- and B. Lev. 1998. The value-relevance of intangibles: The case of software capitalization. Journal of Accounting Research 36 (Supplement): 161-191.

- M. E. Barth, and R. Kasznik. 2001. Stock-based employee compensation and equity market values. Working paper, Stanford University, Stanford, CA.

American Institute of Certified Public Accountants (AICPA), Accounting Principles Board (APB). 1972. Accounting for Stock Issued to Employees. Accounting Principles Board Opinion No. 25. New York, NY: AICPA.

Barth, M. E., W. H. Beaver, J. R. M. Hand, and W. R. Landsman. 1999. Accruals, cash flows, and equity values. Review of Accounting Studies 4 (December): 205-229.

$\longrightarrow,-, \longrightarrow$, and $\longrightarrow$ 2000. Accrual components, earnings forecasting, and equity values. Working paper, The University of North Carolina at Chapel Hill, NC, and Stanford University, Stanford, CA.

- L, and W. R. Landsman. 2001. The relevance of the value relevance literature for financial accounting standard setting: Another view. Joumal of Accounting and Economics 31 (September): 77-104.

—, and G. Clinch. 2001. Scale effects in capital market-based accounting research. Working paper, Stanford University, Stanford CA.

Business Week. 2002. Executive pay. (April 15): 80-100.

Chamberlain, S., and S. Hseih. 1999. The effectiveness of SFAS 123 employee stock option disclosures. Working paper, Santa Clara University, Santa Clara, CA.

Dechow, P. M., A. P. Hutton, and R. G. Sloan. 1999. An empirical assessment of the residual income valuation model. Journal of Accounting and Economics 26 (January): 1-34.

The Economist. 1999. Share options. (August 7): 18-20.

Engel, M. 1997. Long-term incentive plans. In Paying for Performance, edited by P. T. Chingos, 176209. New York, NY: Wiley.

Feltham, G. 1995. Valuation, clean surplus accounting, and anticipated equity transactions. Working paper, University of British Columbia, Vancouver, Canada.

- and J. A. Ohlson. 1995. Valuation and clean surplus accounting for operating and financial activities. Contemporary Accounting Research 11 (Spring): 689-732.

$\longrightarrow$, and 1999 . Residual earnings valuation with risk and stochastic interest rates. The Accounting Review 74 (April): 165-184.

Financial Accounting Standards Board (FASB). 1993. Exposure Draft: Accounting for Stock-Based Compensation. Norwalk, CT: FASB. 
1995. Accounting for Stock-Based Compensation. Statement of Financial Accounting Standards No. 123. Norwalk, CT: FASB.

Hall, B. 1999. Innovation and market value. In Productivity, Innovation, and Economic Performance, edited by B. Ray, G. Mason, and M. O'Mahoney. Cambridge, U.K.: Cambridge University Press. , A. Jaffe, and M. Trajtenberg. 1999. Market value and patent citations: A first look. NBER Working Paper. Cambridge, MA: National Bureau of Economic Research.

Hall, B. J. 2000. What you need to know about stock options. Harvard Business Review (MarchApril): 121-129.

Hand, J. R. M., and W. R. Landsman. 2000. The pricing of dividends and equity valuation. Working paper, The University of North Carolina at Chapel Hill, NC.

Hayn, C. 1995. The information content of losses. Journal of Accounting and Economics 20 (September): 125-153.

Ittner, C., R. Lambert, and D. Larcker. 2002. The structure and performance consequences of equity grants to employees of new economy firms. Journal of Accounting and Economics (forthcoming).

Keating, E., T. Lys, and R. Magee. 2002. The Internet downturn: Finding valuation factors in spring 2000. Journal of Accounting and Economics (forthcoming).

Landsman, W. R., and A. C. Shapiro. 1995. Tobin's Q and the relation between accounting ROI and economic return. Journal of Accounting, Auditing, and Finance 10 (Winter): 103-118.

Morgenson, G. 1998. Stock options are not a free lunch. Forbes (May 18): 213-217.

Ohlson, J. A. 1995. Earnings, equity book values, and dividends in equity valuation. Contemporary Accounting Research 11 (Spring): 661-687.

. 1999. On transitory earnings. Review of Accounting Studies 4 (December): 145-162.

2000. Residual income valuation: The problems. Working paper, New York University, New York, NY.

Stewart, T. 1997. Intellectual Capital. New York, NY: Currency Doubleday.

Vuong, Q. H. 1989. Likelihood ratio tests for model selection and non-nested hypotheses. Econometrica. 57 (March): 307-333.

White, H. 1980. A heteroskedasticity-consistent covariance matrix estimator and a direct test for heteroskedasticity. Econometrica 48 (May): 817-838. 


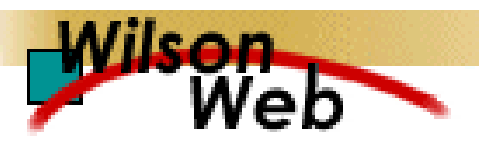

\section{COPYRIGHT INFORMATION}

TITLE: The Valuation Implications of Employee Stock Option Accounting for Profitable Computer Software Firms

SOURCE: The Accounting Review 77 no4 O 2002

WN: 0227404825012

The magazine publisher is the copyright holder of this article and it is reproduced with permission. Further reproduction of this article in violation of the copyright is prohibited. To contact the publisher: http://accounting.rutgers.edu/raw/aaa/index.html.

Copyright 1982-2002 The H.W. Wilson Company. All rights reserved. 